\title{
Thermal properties of mixtures of mineral oil and natural ester in terms of their application in the transformer
}

\author{
Zbigniew Nadolny ${ }^{1, *}$, and Grzegorz Dombek ${ }^{1}$ \\ ${ }^{1}$ Poznan University of Technology, Institute of Electrical Power Engineering, 60965 Poznan, Poland
}

\begin{abstract}
The article describes research results of thermal properties of mineral oil and natural ester. Percentage proportions of both the liquids were as follows: 100/0, 95/5, 80/20, 50/50, 20/80, 0/100. The authors present measurement results of thermal conductivity, viscosity, specific heat, density, and thermal expansion of the created mixtures. The measurements were taken in a relatively wide temperature range: $25^{\circ} \mathrm{C}, 40{ }^{\circ} \mathrm{C}, 60^{\circ} \mathrm{C}$, and $80{ }^{\circ} \mathrm{C}$. On the basis of the measurement results, convection heat transfer coefficient $\alpha$ was calculated and the most advantageous proportion of both the components of the mixture was pointed in terms of cooling effectiveness of the transformer.
\end{abstract}

\section{Introduction}

Insulating liquids are an integral part of the insulating system of most power transformers in the world. Due to their good properties, they have a role of an electric insulation and cooling medium [1-3]. Keeping in mind that heat transport in the transformer proceeds the following way: heat source $\rightarrow$ paper impregnated with liquid $\rightarrow$ insulating liquid $\rightarrow$ tank $\rightarrow$ air; it is liquid properties that will substantially decide about the efficiency of heat transfer [2, 4-6].

The properties which determine the ability of a liquid to heat transfer are: thermal conductivity $\lambda$, kinematic viscosity $v$, specific heat $c_{p}$, density $\rho$, and thermal expansion $\beta$. These properties determine the ability of a liquid to cool the device, i.e. coefficient $\alpha$ [7-9]. The greater this ability is, the higher the value of coefficient $\alpha$. In turn, coefficient $\alpha$ is greater when thermal conductivity, specific heat, density, and liquid thermal expansion are higher and its viscosity is lower $[1,2,5]$.

The most frequently used insulating liquid in power engineering devices is mineral oil [1, 10, 11]. The popularity of applying mineral oil results from its low price and properties which have been well known for decades. Lately, stricter and stricter requirements concerning reliability of power engineering devices and a prospect of a real deficit of petroleum have contributed to search for insulating liquids alternative to mineral oil [12-16].

In the early 1990s, research on transformer liquids of plant origin was initiated. After less than ten years later, commercial application of natural esters was started in distribution transformers. Now we are observing their wider and wider application, including power transformers [11]. The advantages of applying natural esters instead of mineral oil are very good fire properties (high flash and fire point, and low net calorific value) and environmental ones, which include first of all full biodegradability and low toxicity [17-19]. Undoubtedly, another advantage resulting from applying natural esters is also retarding the process of paper insulation ageing of the transformer $[12,20,21]$. Unfortunately, these esters, in comparison to mineral oil, are also characteristic of much higher viscosity and higher solidification temperature $[2,11]$.

Recently research on properties of insulating liquid mixtures has been conducted in many scientific centers in the world. These mixtures can be obtained in two ways. The first one is the so-called retrofilling, which consists in intentional replacing one insulating liquid (most often mineral oil) by another (natural or synthetic esters). This allows, among others, prolonging the remaining operation time of the power device [22]. This process, however, does not guarantee full removing the liquid which filled the transformer before. A small amount of it (not exceeding 8\%) can be deposited in, for example, saturated paper insulation, windings, the core, and other hardly accessible places [23]. Thus as a result of filling the modernized unit with a new insulating liquid, we unintentionally obtain a mixture with the liquid which previously filled the transformer. The other way consists in applying an intended mixture in the new transformer, which consists of two or more insulating liquids of a known proportion. This results in obtaining a mixture, which is characteristic of improvement of some, selected properties in reference to the base liquids [10, $13-15,24,25]$.

Independently of the method how the mixture is created, the purpose of the application is to improve properties of the insulating liquid, which consequently affects the operation period of the transformer. Research on mixtures of insulating liquids which is conducted in many scientific centres all over the world refer mainly to electric properties. The remaining properties, including

\footnotetext{
* Corresponding author: zbigniew.nadolny@put.poznan.pl
} 
thermal properties, attract much less attention, which is not a proper approach. Thus we should take into consideration that applying mixtures of insulating liquids which are characteristic of better electric properties and worse thermal properties in reference to the base liquids, will result in accelerating ageing processes taking place in the insulating system of the transformer and reducing the time of its operation. Therefore, this article presents research results concerning properties that influence the efficiency of transformer cooling properties.

\section{Purpose and range of the research}

The purpose of the undertaken research was to determine the influence of proportions of mineral oil with natural ester on thermal properties of a created mixture. The research range covered the measurement of thermal conductivity $\lambda$, kinematic viscosity $v$, specific heat $c_{p}$, density $\rho$, and thermal expansion $\beta$. On the basis of the measured properties and the equation presented below, coefficient $\alpha$ was determined [8,9]:

$$
\alpha=n+\sqrt[1]{c \cdot \lambda^{1-n} \cdot g^{n} \cdot \delta^{3 n-1} \cdot \beta^{n} \cdot \rho^{n} \cdot c_{p}^{n} \cdot v^{-n} \cdot q^{n}}
$$

where: $\alpha$ - convection heat transfer coefficient of the liquid $\left[\mathrm{W} \cdot \mathrm{m}^{-2} \cdot \mathrm{K}^{-1}\right], c, n-$ constants dependent on the character of the flow, $\lambda$ - thermal conductivity $\left[\mathrm{W} \cdot \mathrm{m}^{-1} \cdot \mathrm{K}^{-1}\right], g-$ acceleration of gravity $\left[\mathrm{m}^{\prime} \mathrm{s}^{-2}\right]$, $\delta$ - characteristic dimension connected with liquid flow $[\mathrm{m}], \beta-$ thermal expansion $\left[\mathrm{K}^{-1}\right], \rho-$ density $\left[\mathrm{g}^{-1}{ }^{-1}\right.$, $c_{p}$ - specific heat $\left[\mathrm{J}^{\mathrm{kg}} \mathrm{kg}^{-1} \cdot \mathrm{K}^{-1}\right], v-$ kinematic viscosity $\left[\mathrm{mm}^{2} \cdot \mathrm{s}^{-1}\right], q-$ surface thermal load $\left[\mathrm{W} \cdot \mathrm{m}^{-2}\right]$. The characteristic dimension $\delta$ was equal to $1 \mathrm{~m}$. By contrast, the values of constants $c$ and $n$ were assumed according to the figures listed in Table 1.

Table 1. Values of constants $c$ and $n$ dependent on the flow type $[8,9]$.

\begin{tabular}{|c|c|c|c|}
\hline Flow type & $\boldsymbol{G r} \cdot \boldsymbol{P r}$ & $\boldsymbol{c}$ & $\boldsymbol{n}$ \\
\hline No flow & $<10^{-3}$ & 0.45 & 0 \\
\hline Laminar flow & $10^{-3}-5 \cdot 10^{2}$ & 1.18 & 0.125 \\
\hline $\begin{array}{c}\text { Transitional } \\
\text { flow }\end{array}$ & $5 \cdot 10^{2}-2 \cdot 10^{7}$ & 0.54 & 0.25 \\
\hline Turbulent flow & $>2 \cdot 10^{7}$ & 0.135 & 0.333 \\
\hline
\end{tabular}

For measurements of thermal properties, the authors used mineral oil named Nytro Taurus manufactured by Nynas and natural ester named Envirotemp FR3 made by Cargil. Both liquids in investigations were new and unused. Water content was 2 ppm in case of mineral oil, and $34 \mathrm{ppm}$ in case of natural ester. Acid number was less than $0,010 \mathrm{mg}_{\mathrm{KOH}} \cdot \mathrm{g}^{-1}$ liquid for mineral oil, and 0,020 $\mathrm{mg}_{\mathrm{KOH}} \cdot \mathrm{g}^{-1}$ liquid for natural ester. Measurements of thermal conductivity of the mixtures were done using authorial measurement system, described in [26]. Measurements of kinematic viscosity, density, and thermal expansion of the mixtures were done using authorial measurements systems according to obligatory standards [27-29]. Measurement of specific heat of the mixtures were done using the differential scanning calorimeter Mettler Toledo DSC1. In order to do the investigations, the authors prepared mixtures of mineral oil and natural ester of the following percentage concentrations of both the liquids: $100 / 0,95 / 5,80 / 20,50 / 50,20 / 80,5 / 95$, and $0 / 100$. The measurements were taken at the temperature of $25{ }^{\circ} \mathrm{C}, 40{ }^{\circ} \mathrm{C}, 60{ }^{\circ} \mathrm{C}$, and $80^{\circ} \mathrm{C}$. The results of the investigations are presented in the following section.

\section{Results and discussion}

\subsection{Thermal conductivity of the mixture of mineral oil and natural ester}

Table 2 and Fig. 1 contain measurement results of thermal conductivity $\lambda$ of a mixture of mineral oil (MO) and natural ester (NE) depending on ester concentration. As we can observe, with increase of natural ester content, thermal conductivity $\lambda$ considerably increases.

Table 2. Measurement results of thermal conductivity $\lambda$ of the mixture of mineral oil (MO) and natural ester (NE).

\begin{tabular}{|c|c|c|c|c|c|}
\hline \multirow{2}{*}{\multicolumn{2}{|c|}{$\begin{array}{l}\text { Proportion of mineral oil } \\
\text { (MO) and } \\
\text { natural ester (NE) }\end{array}$}} & \multicolumn{4}{|c|}{ Temperature $T$} \\
\hline & & $25^{\circ} \mathrm{C}$ & $40^{\circ} \mathrm{C}$ & $60^{\circ} \mathrm{C}$ & $80^{\circ} \mathrm{C}$ \\
\hline & & \multicolumn{4}{|c|}{$\begin{array}{c}\text { Thermal conductivity } \lambda \\
{\left[\mathbf{W} \cdot \mathbf{m}^{-1} \cdot \mathbf{K}^{-1}\right]}\end{array}$} \\
\hline $100 \% \mathrm{MO}$ & $0 \% \mathrm{NE}$ & 0.133 & 0.130 & 0.128 & 0.126 \\
\hline $95 \% \mathrm{MO}$ & $5 \% \mathrm{NE}$ & 0.136 & 0.134 & 0.132 & 0.130 \\
\hline $80 \% \mathrm{MO}$ & $20 \% \mathrm{NE}$ & 0.144 & 0.141 & 0.139 & 0.137 \\
\hline $50 \% \mathrm{MO}$ & $50 \% \mathrm{NE}$ & 0.158 & 0.156 & 0.153 & 0.152 \\
\hline $20 \% \mathrm{MO}$ & $80 \% \mathrm{NE}$ & 0.173 & 0.171 & 0.168 & 0.166 \\
\hline $5 \% \mathrm{MO}$ & $95 \% \mathrm{NE}$ & 0.179 & 0.177 & 0.174 & 0.172 \\
\hline $0 \% \mathrm{MO}$ & $100 \% \mathrm{NE}$ & 0.182 & 0.180 & 0.178 & 0.175 \\
\hline
\end{tabular}

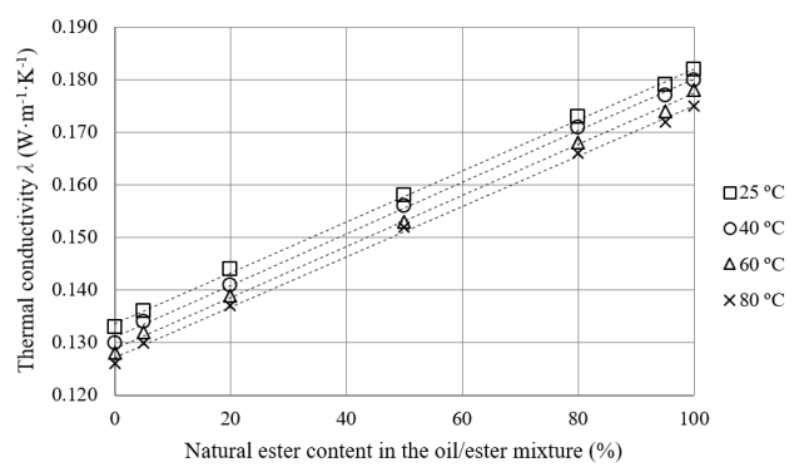

Fig. 1. Thermal conductivity $\lambda$ of the mixture of mineral oil and natural ester. 
This increase is practically linear. The increase of $\lambda$ was equal to $36.8 \%$ (for $25^{\circ} \mathrm{C}$ ), $38.5 \%$ (for $40{ }^{\circ} \mathrm{C}$ ), $39.1 \%$ (for $60{ }^{\circ} \mathrm{C}$ ), and $38.9 \%$ (for $80^{\circ} \mathrm{C}$ ). As we can see, this increase was at a constant level and it practically did not depend on temperature. Summing up, we can say that natural ester increases thermal conductivity of the mixture of mineral oil and natural ester, and consequently they can improve cooling properties of such a mixture.

\subsection{Viscosity of the mixture of mineral oil and natural ester}

Table 3 and Fig. 2 present research results of kinematic viscosity $v$ of the mixture of mineral oil and natural ester, depending on the ester concentration.

Table 3. Measurement results of kinematic viscosity $v$ of the mixture of mineral oil (MO) and natural ester (NE).

\begin{tabular}{|c|c|c|c|c|c|}
\hline \multirow{2}{*}{$\begin{array}{c}\text { Proportion of mineral oil } \\
\text { (MO) and } \\
\text { natural ester (NE) }\end{array}$} & \multicolumn{4}{|c|}{ Temperature } \\
\cline { 3 - 6 } & $25^{\circ} \mathrm{C}$ & $40{ }^{\circ} \mathrm{C}$ & $60{ }^{\circ} \mathrm{C}$ & $80{ }^{\circ} \mathrm{C}$ \\
\cline { 3 - 6 } & \multicolumn{4}{|c|}{$\begin{array}{c}\text { Kinematic viscosity } v \\
{\left[\mathbf{m m}^{2} \cdot \mathbf{s}^{-1}\right]}\end{array}$} \\
\hline $100 \% \mathrm{MO}$ & $0 \% \mathrm{NE}$ & 17.08 & 9.59 & 5.37 & 3.43 \\
\hline $95 \% \mathrm{MO}$ & $5 \% \mathrm{NE}$ & 17.67 & 9.93 & 5.44 & 3.59 \\
\hline $80 \% \mathrm{MO}$ & $20 \% \mathrm{NE}$ & 21.34 & 12.25 & 6.89 & 4.46 \\
\hline $50 \% \mathrm{MO}$ & $50 \% \mathrm{NE}$ & 31.68 & 18.48 & 10.28 & 6.50 \\
\hline $20 \% \mathrm{MO}$ & $80 \% \mathrm{NE}$ & 45.81 & 26.23 & 14.67 & 9.25 \\
\hline $5 \% \mathrm{MO}$ & $95 \% \mathrm{NE}$ & 53.42 & 30.78 & 17.24 & 10.88 \\
\hline $0 \% \mathrm{MO}$ & $100 \% \mathrm{NE}$ & 56.29 & 32.66 & 18.29 & 11.50 \\
\hline
\end{tabular}

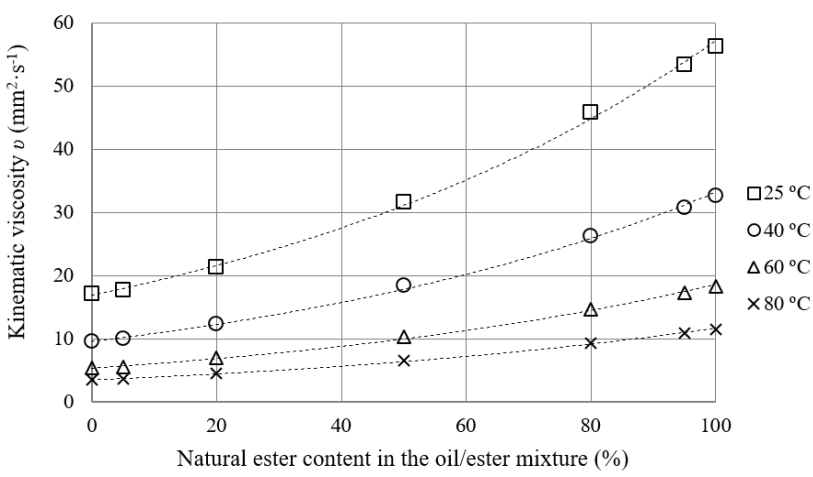

Fig. 2. Kinematic viscosity $v$ of the mixture of mineral oil and natural ester.

As it was shown, increase of natural ester content increases viscosity of the mixture very significantly. Initially, this increase is tiny (up to $5 \%$ of ester content) and next it is very clear (over $5 \%$ of ester content). Increase of viscosity $v$ was equal to $230 \%$ (for $25^{\circ} \mathrm{C}$ ), $241 \%$ (for $40{ }^{\circ} \mathrm{C}$ ), $241 \%$ (for $60{ }^{\circ} \mathrm{C}$ ), and $235 \%$ (for $80{ }^{\circ} \mathrm{C}$ ). This increase, caused by increase of natural ester content in the mixture, was practically independent of temperature. Summing up, we can state that natural ester clearly increases viscosity of the mixture. This fact can result in substantial deterioration of thermal properties of the mixture.

\subsection{Specific heat of the mixture of mineral oil and natural ester}

Table 4 and Fig. 3 present measurement results of specific heat $c_{p}$ of the mixture of mineral oil and natural ester depending on ester concentration. Increase of the natural ester content caused a certain increase of the specific heat of the mixture. This increase was linear. The increase of $c_{p}$ was equal to $6.6 \%$ (for $25^{\circ} \mathrm{C}$ ), $5.4 \%$ (for $40{ }^{\circ} \mathrm{C}$ ), $4.3 \%$ (for $60{ }^{\circ} \mathrm{C}$ ), and $5.7 \%$ (for $80{ }^{\circ} \mathrm{C}$ ). As we can see, the increase of specific heat caused by the increase of the natural ester content in the mixture practically did not depend on temperature. Summing up, we can say that natural ester can slightly improve cooling properties of the mixture of mineral oil and natural ester.

Table 4. Measurement results of specific heat $c_{p}$ of the mixture of mineral oil (MO) and natural ester (NE).

\begin{tabular}{|c|c|c|c|c|c|}
\hline \multirow{2}{*}{$\begin{array}{c}\text { Proportion of mineral } \\
\text { oil (MO) and } \\
\text { natural ester (NE) }\end{array}$} & \multicolumn{5}{|c|}{ Temperature $T$} \\
\cline { 3 - 6 } & $25{ }^{\circ} \mathrm{C}$ & $40{ }^{\circ} \mathrm{C}$ & $60{ }^{\circ} \mathrm{C}$ & $80{ }^{\circ} \mathrm{C}$ \\
\cline { 3 - 6 } Specific heat $c_{p}\left[\mathbf{J}^{2} \mathbf{k g}^{-1} \cdot \mathbf{K}^{-1}\right]$ \\
\hline $100 \% \mathrm{MO}$ & $0 \% \mathrm{NE}$ & 1902 & 1974 & 2077 & 2187 \\
\hline $95 \% \mathrm{MO}$ & $5 \% \mathrm{NE}$ & 1904 & 1975 & 2078 & 2192 \\
\hline $80 \% \mathrm{MO}$ & $20 \% \mathrm{NE}$ & 1925 & 1995 & 2094 & 2212 \\
\hline $50 \% \mathrm{MO}$ & $50 \% \mathrm{NE}$ & 1961 & 2025 & 2119 & 2226 \\
\hline $20 \% \mathrm{MO}$ & $80 \% \mathrm{NE}$ & 1980 & 2036 & 2123 & 2233 \\
\hline $5 \% \mathrm{MO}$ & $95 \% \mathrm{NE}$ & 2024 & 2080 & 2160 & 2257 \\
\hline $0 \% \mathrm{MO}$ & $100 \% \mathrm{NE}$ & 2028 & 2082 & 2166 & 2259 \\
\hline
\end{tabular}

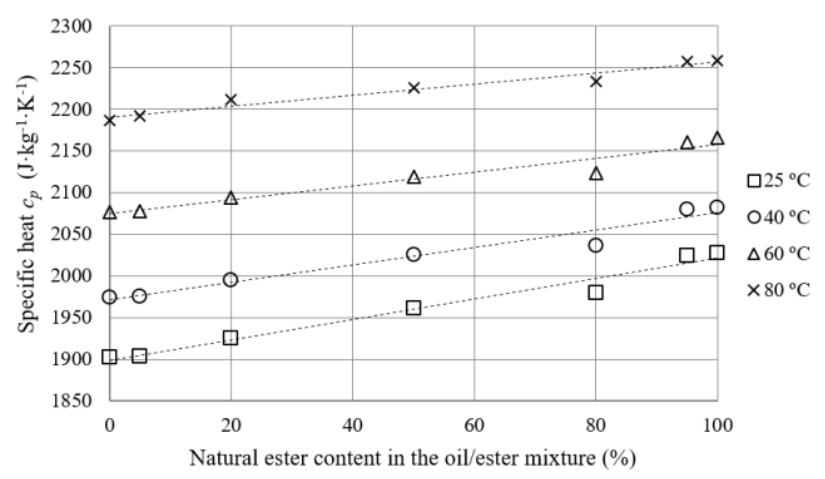

Fig. 3. Specific heat $c_{p}$ of the mixture of mineral oil and natural ester. 


\subsection{Density of the mixture of mineral oil and natural ester}

Table 5 and Fig. 4 present measurement results of density $\rho$ of a mixture of mineral oil and natural ester, depending on ester concentration. As it was shown, the increase of natural ester content caused the linear increase of mixture density. Increase of density $\rho$ was equal to $5.8 \%$ (for $25^{\circ} \mathrm{C}$ ), $6.0 \%$ (for $40{ }^{\circ} \mathrm{C}$ ), $5.6 \%$ (for 60 ${ }^{\circ} \mathrm{C}$ ), and $5.8 \%$ (for $80{ }^{\circ} \mathrm{C}$ ). This increase by a few percent, caused by the increase of natural ester content in the mixture, was practically independent of temperature. Summing up, we can say that increase of natural ester content can cause a slight improvement of cooling abilities of the mixture of mineral oil and natural ester.

Table 5. Measurement results of density $\rho$ of the mixture of mineral oil (MO) and natural ester (NE).

\begin{tabular}{|c|c|c|c|c|c|}
\hline \multirow{2}{*}{$\begin{array}{c}\text { Proportion of mineral oil } \\
\text { (MO) and } \\
\text { natural ester (NE) }\end{array}$} & \multicolumn{4}{|c|}{ Temperature } \\
\cline { 2 - 6 } & $25{ }^{\circ} \mathrm{C}$ & $40{ }^{\circ} \mathrm{C}$ & $60{ }^{\circ} \mathrm{C}$ & $80{ }^{\circ} \mathrm{C}$ \\
\cline { 2 - 6 } & \multicolumn{4}{|c|}{ Density $\boldsymbol{\rho}\left[\mathbf{g} \cdot \mathbf{l}^{-1}\right.$ ] } \\
\hline $100 \% \mathrm{MO}$ & $0 \% \mathrm{NE}$ & 867 & 857 & 845 & 832 \\
\hline $95 \% \mathrm{MO}$ & $5 \% \mathrm{NE}$ & 870 & 860 & 847 & 834 \\
\hline $80 \% \mathrm{MO}$ & $20 \% \mathrm{NE}$ & 877 & 867 & 854 & 842 \\
\hline $50 \% \mathrm{MO}$ & $50 \% \mathrm{NE}$ & 890 & 880 & 869 & 856 \\
\hline $20 \% \mathrm{MO}$ & $80 \% \mathrm{NE}$ & 906 & 896 & 883 & 871 \\
\hline $5 \% \mathrm{MO}$ & $95 \% \mathrm{NE}$ & 915 & 904 & 891 & 878 \\
\hline $0 \% \mathrm{MO}$ & $100 \% \mathrm{NE}$ & 917 & 908 & 892 & 880 \\
\hline
\end{tabular}

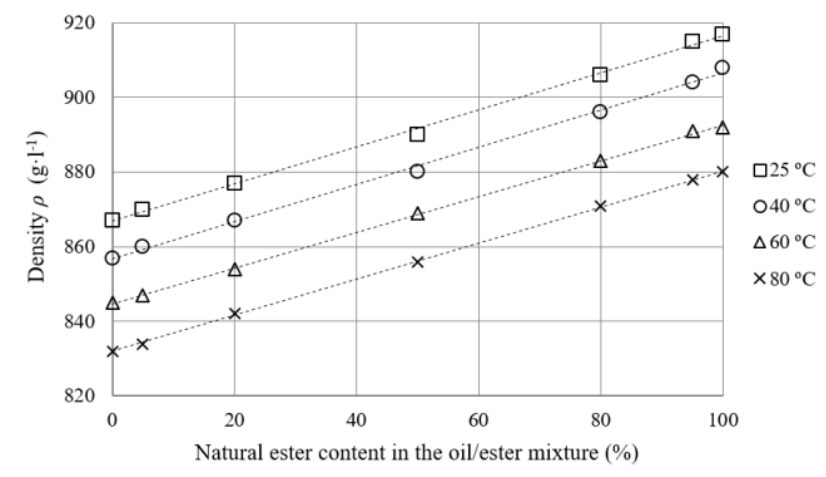

Fig. 4. Density $\rho$ of the mixture of mineral oil and natural ester.

\subsection{Thermal expansion of the mixture of mineral oil and natural ester}

Table 6 and Fig. 5 show measurement results of thermal expansion $\beta$ of a mixture of mineral oil and natural ester depending on ester concentration. As we can see, increase of natural ester content practically did not cause any changes of thermal expansion of the mixture. The lack of expansion changes was noted for all the temperature values. Thus we can say that increase of natural ester content does not result in any changes of cooling abilities of an analyzed mixture.

Table 6. Measurement results of thermal expansion $\beta$ of the mixture of mineral oil (MO) and natural ester (NE).

\begin{tabular}{|c|c|c|c|c|c|}
\hline \multirow{2}{*}{$\begin{array}{c}\text { Proportion of mineral } \\
\text { oil (MO) and } \\
\text { natural ester (NE) }\end{array}$} & \multicolumn{5}{|c|}{ Temperature $T$} \\
\cline { 3 - 6 } & $25{ }^{\circ} \mathrm{C}$ & $40{ }^{\circ} \mathrm{C}$ & $60{ }^{\circ} \mathrm{C}$ & $80{ }^{\circ} \mathrm{C}$ \\
\cline { 3 - 6 } & \multicolumn{3}{|c|}{ Thermal expansion $\beta\left[\mathrm{K}^{-1}\right]$} \\
\hline $100 \% \mathrm{MO}$ & $0 \% \mathrm{NE}$ & 0.00075 & 0.00076 & 0.00078 & 0.00080 \\
\hline $95 \% \mathrm{MO}$ & $5 \% \mathrm{NE}$ & 0.00075 & 0.00076 & 0.00078 & 0.00081 \\
\hline $80 \% \mathrm{MO}$ & $20 \% \mathrm{NE}$ & 0.00076 & 0.00077 & 0.00078 & 0.00081 \\
\hline $50 \% \mathrm{MO}$ & $50 \% \mathrm{NE}$ & 0.00075 & 0.00077 & 0.00079 & 0.00080 \\
\hline $20 \% \mathrm{MO}$ & $80 \% \mathrm{NE}$ & 0.00075 & 0.00076 & 0.00078 & 0.00081 \\
\hline $5 \% \mathrm{MO}$ & $95 \% \mathrm{NE}$ & 0.00075 & 0.00076 & 0.00079 & 0.00081 \\
\hline $0 \% \mathrm{MO}$ & $100 \% \mathrm{NE}$ & 0.00074 & 0.00076 & 0.00078 & 0.00080 \\
\hline
\end{tabular}

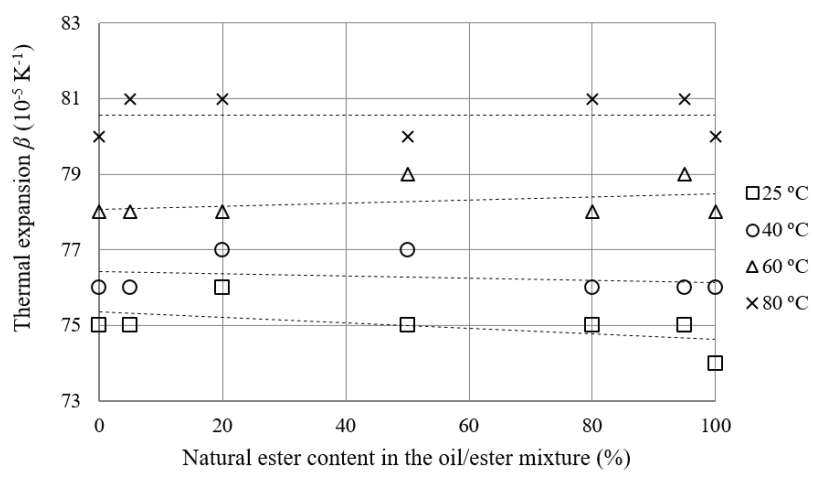

Fig. 5. Thermal expansion $\beta$ of the mixture of mineral oil and natural ester.

\subsection{Convection heat transfer coefficient of the mixture of mineral oil and natural ester}

Table 7 and Fig. 6 present calculation results of the convection heat transfer coefficient $\alpha$ of a mixture of mineral oil and natural ester depending on ester concentration. The calculations of coefficient $\alpha$ were done on the basis of the measurement results presented in the previous subsections (3.1-3.5).

As it results from the table and the figure, with increase of natural ester content in the mixture, its coefficient $\alpha$ was initially rising a little (up to $5 \%$ of ester content) and next it was clearly decreasing (starting from $5 \%$ of ester content). This trend could be observed independently of temperature. The initial increase of coefficient $\alpha$ (up to $5 \%$ of ester content) was very small and it was merely $0.4 \%$ (for $25^{\circ} \mathrm{C}$ ), $0.8 \%$ (for $40{ }^{\circ} \mathrm{C}$ ), $1.3 \%$ (for $60{ }^{\circ} \mathrm{C}$ ), $0.9 \%$ (for $80{ }^{\circ} \mathrm{C}$ ). In turn, the drop of coefficient $\alpha$ (starting from $5 \%$ of ester content) was 
more significant and it was $4.5 \%$ (for $25^{\circ} \mathrm{C}$ ), $4.8 \%$ (for $40{ }^{\circ} \mathrm{C}$ ), $5.4 \%$ (for $60{ }^{\circ} \mathrm{C}$ ), and $8.1 \%$ (for $80{ }^{\circ} \mathrm{C}$ ).

Table 7. Measurement results of convection heat transfer coefficient $\alpha$ of the mixture of mineral oil (MO) and natural ester (NE).

\begin{tabular}{|c|c|c|c|c|c|}
\hline \multirow{3}{*}{\multicolumn{2}{|c|}{$\begin{array}{c}\text { Proportion of } \\
\text { mineral oil (MO) } \\
\text { and } \\
\text { natural ester (NE) }\end{array}$}} & \multicolumn{4}{|c|}{ Temperature $T$} \\
\hline & & $25^{\circ} \mathrm{C}$ & $40{ }^{\circ} \mathrm{C}$ & $60^{\circ} \mathrm{C}$ & $80^{\circ} \mathrm{C}$ \\
\hline & & \multicolumn{4}{|c|}{$\begin{array}{c}\text { Convection heat transfer coefficient } \\
\alpha\left[\mathbf{W}^{-} \mathbf{m}^{-2} \cdot \mathbf{K}^{-1}\right]\end{array}$} \\
\hline $100 \% \mathrm{MO}$ & $0 \% \mathrm{NE}$ & 93.56 & 107.89 & 125.70 & 141.65 \\
\hline $95 \% \mathrm{MO}$ & $5 \% \mathrm{NE}$ & 93.92 & 108.70 & 127.32 & 142.86 \\
\hline $80 \% \mathrm{MO}$ & $20 \% \mathrm{NE}$ & 92.94 & 106.63 & 123.67 & 139.56 \\
\hline $50 \% \mathrm{MO}$ & $50 \% \mathrm{NE}$ & 88.65 & 101.98 & 118.64 & 134.15 \\
\hline $20 \% \mathrm{MO}$ & $80 \% \mathrm{NE}$ & 85.18 & 97.98 & 113.91 & 129.43 \\
\hline $5 \% \mathrm{MO}$ & $95 \% \mathrm{NE}$ & 84.04 & 96.60 & 112.44 & 127.12 \\
\hline $0 \% \mathrm{MO}$ & $100 \% \mathrm{NE}$ & 83.46 & 96.12 & 111.80 & 126.17 \\
\hline
\end{tabular}

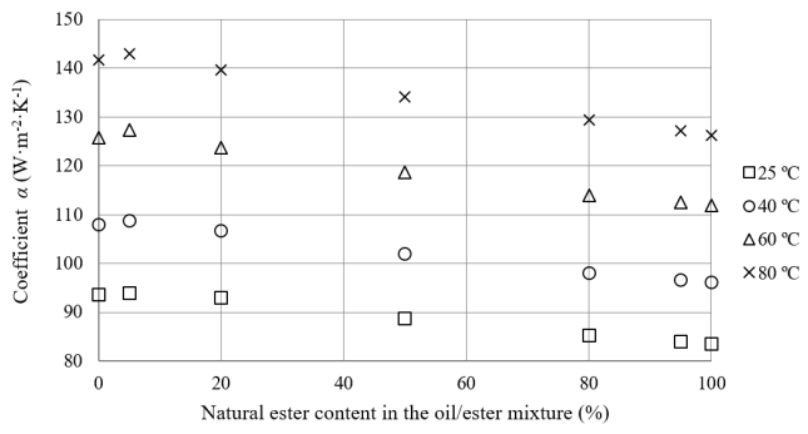

Fig. 6. Convection heat transfer coefficient $\alpha$ of the mixture of mineral oil and natural ester.

The initial increase of coefficient $\alpha$ caused by increase of ester content in the mixture (up to $5 \%$ ) resulted from many effects. These include the increase of thermal conductivity, specific heat, and density, despite a slight increase of viscosity. In turn, the drop of coefficient $\alpha$ (over $5 \%$ of ester content) was caused by a violent viscosity increase, despite resulting increase of thermal conductivity, specific heat, and density. We can say on this basis that the best combination of the mixture components is $95 \%$ of mineral oil and $5 \%$ of natural ester.

\section{Conclusions}

The increase of natural ester content in the mixture of mineral oil and natural ester resulted in increase of thermal conductivity by almost $40 \%$, viscosity increase by over $200 \%$, specific heat increase by about $5 \%$, density increase by about $5 \%$, and no changes of thermal expansion. In contrast, coefficient $\alpha$ has its maximum for a mixture of $95 \%$ of mineral oil and $5 \%$ of natural ester.
Coefficient $\alpha$ was $141.65 \mathrm{~W} \cdot \mathrm{m}^{-2} \cdot \mathrm{K}^{-1}$ in case of pure mineral oil and $142.86 \mathrm{~W} \cdot \mathrm{m}^{-2} \cdot \mathrm{K}^{-1}$ in case of mixture with maximal convection heat transfer coefficient, for $80{ }^{\circ} \mathrm{C}$ (Table 7). Temperature decrease $\Delta T$ (between windings and tank) for pure oil is $24.7{ }^{\circ} \mathrm{C}$, and for mixture with maximal $\alpha$ is $24.5^{\circ} \mathrm{C}$ (surface heat density equals $3500 \mathrm{~W} \cdot \mathrm{m}^{-2}$ ). It means that difference of $\Delta T$ between pure oil and mixture whit maximal $\alpha$ is just $0.2^{\circ} \mathrm{C}$.

From the practical point of view we can say that it makes no sense to apply the mixture $(95 \%$ of mineral oil and $5 \%$ of natural ester) of the maximum coefficient $\alpha$. This results from the fact that for such a mixture, this coefficient is only by $1-2 \%$ higher than for the coefficient $\alpha$ of pure mineral oil.

In the case of retrofilling, i.e. replacing mineral oil with ester (e.g. natural ester), we can expect that a few percent of oil will remain in the transformer in its hardly available parts (paper insulation, crevices). In this way, a mixture of oil and ester is created of the proportion 5/95. The coefficient $\alpha$ of such a mixture (Table 7, Figure 6) is much lower than the coefficient $\alpha$ of pure mineral oil or the mixture of the maximum value of $\alpha$. Thus we can expect that after retrofilling the transformer, the created mixture will have worse cooling properties. On the other hand, the coefficient $\alpha$ of the mixture is a slightly higher than the coefficient $\alpha$ of pure natural ester. Thus we can expect that after retrofilling the transformer, the created mixture will have better cooling properties than natural ester.

Measured values of thermal properties of mixtures (thermal conductivity, kinematic viscosity, specific heat, density, and thermal expansion) were intermediate values of pure oil and pure natural ester. But coefficient $\alpha$ values, calculated using formula (1), were not intermediate values of pure oil and pure natural ester. The coefficient $\alpha$ had some unexpected maximum, what is important results.

Future investigations of a mixture with used mineral oil and unused natural ester should be made in order to better understanding of thermal consequence of retrofilling the transformer.

The research was financed from resources of the Ministry of Sciene and Higher Education for statutory activities No. 04/41/DS-PB/4293, name of the task: The Influence of Various Parameters on Thermal Properties of Dielectric Liquids Used in High Voltage Transformer.

\section{References}

1. T.O. Rouse, IEEE Electr. Insul. Mag. 14 (1998)

2. G. Dombek, Z. Nadolny, Eksploatacja i Niezawodnosc - Maintenance and Reliability $\mathbf{1 8}$ (2016)

3. Z. Nadolny, G. Dombek, P. Przybylek, IEEE 2016 Conf. Electr. Insul. Dielectr. Phenom., 857-860 (2016)

4. R. Lopatkiewicz, Z. Nadolny, Prz. Elektrotechniczny 84 (2008) 
5. Z. Nadolny, G. Dombek, P. Przybylek, D. Przadka, IEEE 2016 Conf. Electr. Insul. Dielectric Phenom., 538-541 (2016)

6. R. Lopatkiewicz, Z. Nadolny, P. Przybylek, W. Sikorski, Prz. Elektrotechniczny 88 (2012)

7. F.B. Waddington, GEC J. Sci. Technol. 49 (1983)

8. F.P. Incropera, D.P. DeWitt, T.L. Bergman, A.S. Lavine, Fundamental of heat and mass transfer (Willey, 2007)

9. R. Rudramoorthy, K. Mayilsamy, Heat and mass transfer (Pearson, 2011)

10. R. Liao, J. Hao, S. Grzybowski, IEEE 2011 Int. Conf. Dielectric Liq., 1-4 (2011)

11. Cigre WG A2.35, Experience in service with new insulating liquids. Brochure 436 (Cigre, Paris, 2010)

12. Y. Bertrand, L.C. Hoang, Int. Conf. Prop. Appl. Dielectric Mater., 491-494 (2003)

13. I. Fofana, V. Wasserberg, H. Borsi, E. Gockenbach, IEEE Electr. Insul. Mag. 18 (2002)

14. I. Fofana, V. Wasserberg, H. Borsi, E. Gockenbach, IEEE Electr. Insul. Mag. 18 (2002)

15. C. Perrier, J.L. Beroual, L. Bessade, IEEE Trans. Dielectr. Electr. Insul. 13 (2006)

16. T. Boczar, A. Cichon, S. Borucki, IEEE Trans. Dielectr. Electr. Insul. 21 (2014)

17. K. Longva, Nordic Insul. Symp., 293-295 (2005)

18. T.V. OOmmen, IEEE Electr. Insul. Mag. 18 (2002)

19. C.P. McShane, J.L. Corkran, K.J. Rapp, J. Luksich, Conf. Electr. Insul. Dielectric Phenom., 124-127 (2003)

20. L. Ruijin, H. Jian, C. George, M. Zhigin, Y. Lijm, IEEE Trans. Dielectr. Electr. Insul. 18, 1626-1637 (2011)

21. P. Trnka, V. Mentlik, M. Svoboda, IEEE Int. Conf. Dielectric Liq., 1-4 (2014)

22. C.P. McShane, J. Luksich, K.J. Rapp, IEEEIAS/PCA Cem. Ind. Tech. Conf., 141-147 (2003)

23. I. Fofana, V. Wasserberg, H. Borsi, E. Gockenbach, IEEE Electr. Insul. Mag. 17, 17-30 (2001)

24. R. Liao, J. Hao, L. Yang, S. Liang, J. Yin, Int. Conf. High Voltage Eng. Appl., 588-591 (2010)

25. C.P. McShane, IEEE-IAS/PCA Cem. Ind. Tech. Conf., 31-40 (2001)

26. G. Dombek, Z. Nadolny, P. Przybylek, Prz. Elektrotechniczny, 148-151 (2014)

27. ASTM D 1903-08

28. ISO 3675:1998

29. ISO 3104:1994 